\title{
LITERATURA E DIREITOS HUMANOS: A REPRODUÇÃO DO MAL EM MEMÓRIAS Póstumas de Brás Cubas'
}

\author{
Paulo Sérgio Gomes Soares ${ }^{2}$ \\ Universidade Federal do Tocantins
}

\section{RESUMO:}

O artigo mostra como o mal se reproduz nas relações sociais historicamente constituídas, exemplificado no romance/ficção machadiano, Memórias póstumas de Brás Cubas, cujo pano de fundo é a escravidão. Situações rememoradas por Brás Cubas revelam os padrões sociais de humanidade da época, analisados à luz dos conceitos de maldade e perversidade. A reprodução do mal possui raízes na introjeção/internalização dos valores sociais e morais e conduz a uma reflexão acerca das ilusões do humanismo e do papel dos Direitos Humanos hoje.

\section{ABSTRACT:}

This article shows how cruelty is reproduced in historically constructed social relations, exemplified in Machado's romantic fiction novel, Posthumous Memories of Brás Cubas, whose background is slavery. Situations recollected by Brás Cubas reveal the social standards of the humanity of that time, analyzed in the light of the concepts of cruelty and wickedness. The reproduction of cruelty has its roots in the introjection/internalization of social and moral values and leads to a reflection about the illusions of humanism and the role of human rights today.

\section{PALAVRAS-CHAVE:}

Filosofia. Literatura.

Direitos Humanos.

Reprodução do Mal.

Maldade. Perversidade.

\section{KEYWORDS:}

Philosophy. Literature.

Human rights.

Reproduction of cruelty. Cruelty. Wickedness.

\footnotetext{
${ }^{1}$ Embora tenha passado por várias alterações, inclusive no título, esse texto foi apresentado no VII Colóquio Internacional Filosofia e Ficção: a arte da vingança, promovido pelo Instituto de Filosofia, Artes e Cultura (IFAC), da Universidade Federal de Ouro Preto, em Minas Gerais, no período de 17 a 20 de agosto de 2015.

${ }^{2}$ Licenciado em Filosofia. Mestre em Epistemologia, Lógica e Filosofia da Ciência. Doutor em Educação. Professor de Filosofia na Graduação em Filosofia e no Programa de Pós-Graduação em Prestação Jurisdicional e Direitos Humanos da Universidade Federal do Tocantins, Campus de Palmas.
} 


\section{Situando o problema da reprodução do mal}

O livro Memórias póstumas de Brás Cubas, publicado originalmente em 1881, por um dos maiores mestres da literatura brasileira - Joaquim Maria Machado de Assis -, expõe algumas situações pontuais que permitem uma reflexão sobre a natureza do mal e sua reprodução como uma construção social, bem como compreender a autorreflexão machadiana acerca da própria escravidão.

No prólogo, ao responder a Capistrano de Abreu se o livro é um romance, Machado de Assis disse o seguinte: "há na alma deste livro, por mais risonho que pareça, um sentimento amargo e áspero, que está longe de vir dos seus modelos. É taça que pode ter lavores de igual escola, mas leva outro vinho"3. Esse sentimento amargo e áspero perpassa o livro todo e suspeitamos que expressa as próprias convicções machadianas em relação ao processo civilizatório e expõe seu entendimento acerca do papel do crítico literário, dele (Machado de Assis) no que tange aos horrores da escravidão. Como também, deixa o seu recado em relação às "ilusões do humanismo", quando faz Brás Cubas dizer, no final do livro, que não teve filhos e não legou sua miséria para a posteridade.

De fato, Machado de Assis foi casado durante 35 anos com Carolina Xavier de Novais e não teve filhos. Nasceu pobre, no Morro do Livramento, Rio de Janeiro, em 21 de junho de 1839, filho de Francisco José de Assis e de Maria Leopoldina Machado de Assis, ambos, escravos alforriados. Não teve filhos, mas pariu livros que o imortalizaram após a sua morte em 29 de setembro de 1908.

$\mathrm{O}$ autor teve um período relativamente curto como crítico literário, profissão que abandonou por volta de 1880 para não se indispor e "não ferir suscetibilidades", bem como para não dificultar sua ascensão social e literária. Em sua concepção a crítica deveria servir como crítica e autocrítica, postura diferente do seleto círculo de homens de letras do qual fazia parte, em fins do século XIX. Esse círculo se apegava ao exercício tradicional da crítica literária de objetivamente "reproduzir a cor local como critério de aferição de 'brasilidade' do texto literário", enquanto Machado de Assis propunha um realismo acercado de intensa autorreflexividade.

De certa forma, isso responde objetivamente à pergunta feita por Capistrano de Abreu, que o próprio Machado de Assis indiretamente procurou responder no prólogo do livro: "é taça que pode ter lavores de igual escola, mas leva outro vinho", agora mais encorpado pela autorreflexão.

Machado de Assis direcionou sua produção para a ficção e manteve a crítica literária no interior dos seus textos. O livro Memórias Póstumas de Brás Cubas segue esse direcionamento e sua forma de escrita inaugura na ficção brasileira a autorreflexão como objeto de criação, tendo como pano de fundo a própria sociedade carioca, os costumes da elite da época e sua relação com temas como a escravidão. Nossa hipótese é que esse romance, que chama a atenção, em momentos específicos, para a escravidão, é também uma ficção que denuncia a reprodução do mal.

Procuramos trilhar por caminhos que apontam que o fenômeno da reprodução do mal é fruto da contradição entre as exigências instintivas (natureza) e as restrições da civilização (cultura). Nesse sentido, o objetivo desse artigo é mostrar como o mal se reproduz entre os seres humanos como uma construção social, utilizando como pano de fundo o livro Memórias póstumas de Brás Cubas.

Há situações relatadas pela personagem Brás Cubas em que ele é sujeito e objeto de sua própria

\footnotetext{
${ }^{3}$ MACHADO DE ASSIS, J. M. Memórias póstumas de Brás Cubas. São Paulo: Abril, 2010, p. 17-18.

${ }^{4}$ A expressão se refere aos limites e interesses do ser humano enquanto crenças que sustentam o processo civilizatório.

${ }^{5}$ AZEVEDO, Sílvia M. A educação do leitor em Machado de Assis: da crítica literária à Memórias póstumas de Brás Cubas. TRANS/FORM/AÇÃO: Revista de Filosofia. (Fundação para o Desenvolvimento da UNESP). São Paulo, Vol. 13, 1990, p. 95.

${ }^{6}$ MACHADO DE ASSIS, op. cit., 2010, p. 17-18.
} 
maldade, indo além, revelando aspectos de perversidade intocados pelos padrões sociais de humanidade da época. A sua consciência de "autor defunto" revive e parece trazer consigo certo sentimento de culpa, que é a culpa de que o próprio processo civilizatório ocidental padece, ainda hoje, pelo sofrimento que imputou aos povos africanos durante os séculos de escravidão. Para Freud ${ }^{7}$, o sentimento de culpa é o mais importante problema a ser considerado no desenvolvimento da civilização, por ser crucial para a compreensão do instinto de destruição. A reprodução do mal se funda nesse instinto destrutivo e as memórias póstumas do defunto autor mostram o funcionamento desse mecanismo.

O segundo tópico deste artigo aponta a diferença conceitual entre maldade e perversidade, conforme o filósofo Patrick Vignoles ${ }^{8}$, fundamental para analisar a conduta da personagem Brás Cubas, sobretudo quando criança, e da própria elite da época e seus valores em relação à escravidão.

Ora, o comportamento de Brás Cubas é maldoso e perverso e ganha vida pela tinta machadiana, mas com diferentes conotações que nos permitem refletir sobre a natureza do mal e sua reprodução, considerando situações em que evidenciam sua introjeção/internalização e latência. A reprodução, portanto, vai acontecer devido à latência, mas de maneira imprevisível, como mais adiante se mostra. Da mesma forma que não há ferida que não cicatrize, não há mal que não leve a um outro. Então, em princípio, pode-se afirmar que o mal é um problema ético, mas suspeitamos que a sua ausência é uma ilusão do humanismo.

Enfim, o texto não tem a pretensão de fazer qualquer discurso legitimador da violência natural e nem tampouco de defender qualquer forma de biologia social e reduzir o ser humano à vida natural. $\mathrm{O}$ pressuposto naturalista de nossa origem animal causa desconforto, mas é parte de nossa constituição inserida no contexto do humanismo. A humanidade está entre essas duas perspectivas: o naturalismo e o humanismo.

Desnaturalizada ou, ao contrário, eminentemente naturalizada, nós temos muita dificuldade em nos acomodarmos com esta origem, não sabendo situá-la no lugar preciso onde ela deveria se encontrar. De um lado, o humanismo dá tudo ao homem: o Pensamento, a Razão, a Sociabilidade e a Técnica, ou seja, qualidades absolutas que fazem do homem, já de saída, um ser fora da natureza ou metafísico. Este humanismo de direito divino não é somente algo do passado: nós somos secretamente cúmplices dele a cada vez que, empregando palavras que nos instalam dogmaticamente em plena humanidade, nós ocultamos o processo de hominização sob atributos eternos. Por outro, nós sabemos, por causa de nossa ciência atual, que somos uma espécie advinda e mesmo tardiamente surgida na história da natureza. ${ }^{9}$

O fenômeno humano foi naturalizado e a humanidade se tornou uma experiência que confere a cada homem a dignidade e o direito que, por conseguinte, desanimaliza-o, concedendo-lhe um valor absoluto que não se compara aquilo que se destina aos animais. Entretanto, Bimbenet aponta que o processo de hominização é uma construção metafísica, uma aspiração idealizada, uma ilusão necessária ao processo civilizatório, que procura nos desvencilhar de nossa origem animal, mas que no fundo a pressupõe. Somos animais humanos e as verdades opostas - naturalismo e humanismo - acomodam-se e perfazem a ideia de "natureza humana". Um sem o outro é pobre e limitado, isto é, incorrem num reducionismo, tendo em vista que o humanismo recusaria o evolucionismo e conferiria privilégios absolutos aos seres humanos (antropocentrismo) e o naturalismo, por sua vez, deixaria escapar a dignidade e o direito. "Assim, precisamos pensar o homem ao mesmo tempo como um fato natural e como portador de valores absolutos, tal como se misturássemos a água e o fogo." 10

\footnotetext{
${ }^{7}$ FREUD, Sigmund. O futuro de uma ilusão, O mal-estar na civilização e outros trabalhos (1927-1931). Trad. Jayme Salomão. Vol. XXI. Rio de Janeiro: Imago, 1996.

${ }^{8}$ VIGNOLES, Patrick. A perversidade. Trad. Nícia A. Bonatti. Campinas/SP: Papirus, 1991.

${ }^{9}$ BIMBENET, Étienne. O animal que não sou mais. Trad. Maurício José d'Escragnolle Cardoso. Curitiba/PR: Ed. UFPR, 2014, p. 18.

${ }^{10}$ Ibidem, p. 26.
} 
O fato é que para este artigo sobre a reprodução do mal, faz-se necessário atiçar o conflito, evidenciando que as ilusões humanistas retiram do homem a sua condição originariamente animal, mas que precisamos recolocá-la para explicar tal fenômeno, que traz à tona as consequências da repressão instintual características da cultura. Há um antagonismo irremediável entre as coerções e restrições da civilização e as exigências do instinto. O processo civilizatório é repressivo e exige a renúncia instintual, mas se apoia no antagonismo entre opressores e oprimidos. "Fica-se com a impressão de que a civilização é algo que foi imposto a uma maioria resistente por uma minoria que compreendeu como obter a posse dos meios de poder e coerção." 11

O curso do desenvolvimento humano mostra que a coerção externa, bem como as restrições, são gradativamente introjetadas/internalizadas pelos indivíduos e o papel da cultura é torná-los veículos de disseminação e perpetuação de suas características. "Acha-se em consonância com o curso do desenvolvimento humano que a coerção externa se torne gradativamente internalizada, pois um agente mental especial, o superego do homem, a assume e a inclui entre seus mandamentos." 12 . A coerção externa transforma os indivíduos. O superego é um aparato repressor interno com importante vantagem cultural, no campo psicológico, pois os opositores se tornam veículos da civilização, evitando medidas externas de coerção.

Então, por um lado o superego serve ao processo civilizatório, porque separa o homem da sua condição animal primordial pela inserção na cultura, embora produza o efeito colateral ao qual Freud aponta não haver saída - a eliminação gradual da liberdade em função da repressão. Em outras palavras, o pressuposto freudiano sugere que a repressão sobre a natureza é necessária ao processo civilizatório, embora, contraditoriamente, gere o mal-estar com o qual a cultura tem de conviver: a liberdade restringida é fonte de insatisfação e frustração, que conduzem a outros efeitos.

Por outro lado, de um ponto de vista político, o superego internaliza a ordem vigente, isto é, torna o indivíduo um reprodutor do padrão societário.

Os valores escravocratas são observados na personagem Prudêncio, um preto liberto, que introjetou/ internalizou a cultura dominante e passou a ser um veículo dela. Ele comprou um escravo e foi visto vergalhando-o em público, como que reproduzindo o mal que sofreu, respondendo ora exigências instintivas, ora aos padrões de humanismo da época.

Esses dados são perturbadores. Significam que os valores da escravidão eram aceitos por quase toda a sociedade. Mesmo os escravos, embora lutassem pela própria liberdade, embora repudiassem sua escravidão, uma vez libertos admitiam escravizar os outros. Que os senhores achassem normal ou necessária a escravidão, pode entenderse. Que libertos o fizessem, é matéria para reflexão. ${ }^{13}$

A proposta do artigo é exatamente essa, refletir sobre esse fenômeno e apontar possíveis respostas acerca do comportamento ajustado aos padrões do humanismo, mas, ao mesmo tempo, reprodutor da violência e alienado em relação à miséria, a dominação e todas as dificuldades inerentes à luta pela existência.

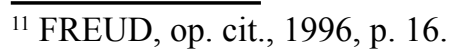

12 Ibidem, p. 21.

${ }^{13}$ CARVALHO, José Murilo de. Cidadania no Brasil: o longo caminho. 14ª ed. Rio de Janeiro: Civilização Brasileira, 2011, p. 49.
} 


\section{Reflexão e autorreflexão acerca da escravidão: maldade e perversidade nas Memórias póstumas de Brás Cubas}

O mal afeta direta e indiretamente o ser humano, fazendo com que pensemos sobre ele e busquemos indícios de sua origem no tempo e no espaço. O mal existe e a sua existência não exige maior prova: "existo e portanto sofro com o mal"14.

A maldade é diferente da perversidade.

A reflexão filosófica e moral pressente que as palavras 'maldade' e 'perversidade' distinguem-se não somente pela sua significação mas pelo seu interesse filosófico. Precisamente, a perversidade nos questiona e nos inquieta mais que a maldade, uma vez que a primeira seria a causa da segunda: a maldade ou agressividade em relação a outrem seria o produto de uma perversidade constitutiva do ser humano. Mesmo se a descobrimos em atos de maldade particular, anormal, a perversidade sugere que o mal como disposição e ato é uma dimensão inata e, por isso mesmo, angustiante, senão desesperadora, da humanidade. ${ }^{15}$

Para o autor, a perversidade se apresenta como uma disposição humana, como algo potencial e latente, diferentemente da maldade, que é circunstancial e definida em seus limites. Alguém maldoso pratica o mal, podendo ser qualificado como desonesto, injusto, contraventor, etc., mas alguém perverso está a serviço do mal, não sendo possível meramente qualificá-lo, pois a perversidade é indeterminada. O mal "é o meio ou o elemento da perversidade, o ser perverso vive o mal"16. O indivíduo que vive o mal está pronto para tudo, isto é, possui disposição para todo o mal.

O fenômeno do mal é retrospectivo. No caso da maldade só acontece efetivamente quando cometida e completada, permitindo a imputação e/ou acusação a alguém após ter cometido uma agressão, um furto, um roubo qualificado, um xingamento, etc. O problema da perversidade, por sua vez, está na imprevisibilidade, no comportamento prenhe, na latência reservada para o futuro. O perverso vive e busca o mal, inventa maneiras de praticá-lo e dele se pode esperar o pior, considerando a sua imprevisibilidade.

Socialmente dizendo, o contexto da escravidão e o contexto do nazismo podem evidenciar a diferença entre o comportamento meramente maldoso de uma disposição à perversidade. As atrocidades cometidas durante o holocausto na Europa sob o domínio nazista e durante a escravidão no Brasil excederam o repertório de maldades cometidas contra os judeus e contra os povos africanos, transformando-se em perversidade.

Durante o domínio nazista, não bastou humilhar e segregar os judeus em guetos, sendo necessário inventar uma "solução final", execuções em câmaras de gás, fuzilamentos, etc., para dizer que a novidade não estava na morte, mas na sentença de que os judeus não mereciam viver entre nós e que a única solução estava no extermínio. A palavra extermínio indicava que estava autorizado inventar meios para matar pessoas em massa. A perversidade estava primeiramente na invenção e, depois, na execução, nessa ordem, pois a execução é inferior se comparada à sua concepção, que produz um sinistro prazer.

Em outras palavras, o nazismo que já é o pior, teria podido ser ainda pior: ele foi tão longe na invenção das formas do mal, que poderia ter ido ainda mais longe, e ele teria ido mais longe ainda se tivesse durado mais tempo. Além da lei, que é limite, efetivamente já não existem limites. É o princípio da escalada: a lógica do mal é ir de mal a pior. ${ }^{17}$

\footnotetext{
${ }^{14}$ RUSSELL, Jeffrey B. O diabo: as percepções do mal da Antiguidade as Cristianismo Primitivo. Trad. Waltensir Dutra. Rio de Janeiro: Campus, 1991, p. 01.

${ }^{15}$ VIGNOLES, op. cit., 1991, p. 13.

${ }^{16}$ Ibidem, p. 54.

${ }^{17}$ Ibidem, p. 57.
} 
Ora, o modelo de reprodução do mal nazista foi interrompido, embora não o preconceito, a xenofobia e o racismo. O fim da Segunda Guerra Mundial gerou uma profunda reflexão sobre o processo civilizatório, sobretudo diante dos seis milhões de judeus exterminados nos campos de concentração, em experiências, em fuzilamentos sumários, etc., dentre outros povos, como ciganos e africanos e até dissidentes políticos do regime e homossexuais.

O mesmo se pode dizer da escravidão no Brasil, somente contida por interesses econômicos, mas que poderia ter ido além se tivesse tido mais tempo, se não contrariasse os interesses e as regras do mercado. Milhares de africanos morreram nos navios negreiros, em terras brasileiras por exaustão devido ao trabalho forçado em atividades embrutecedoras ou sentindo dor nos instrumentos de tortura.

Durante todo o período da escravidão, não bastou tratar homens e mulheres como animais ${ }^{18} \mathrm{e}$ escravizar os povos africanos, o que em si denunciaria a maldade de uma nação contra a outra, de um ser humano contra o outro. $\mathrm{O}$ mal foi ainda maior e disposto na diversidade dos instrumentos de tortura, que eram invenções para fazer sofrer; instrumentos que denunciam a subjetividade perversa que desejava produzir sempre mais sofrimento. Nesse sentido, cabe ressaltar a distinção entre a maldade e a perversidade, como um critério fundamental para indicar se o mal cometido contra os pretos durante a escravidão se enquadra como maldade ou se pode ser caracterizado como perversidade.

Como se argumenta e denuncia, portanto, há os traços evidentes de perversidade. Naquele momento, estava suspensa a antinomia entre naturalismo e humanismo, considerando que o humanismo secularizado das religiões e socialmente internalizado negava aos escravos a dignidade e os direitos de humanidade dos brancos, fazendo prevalecer no seu espectro o naturalismo, isto é, ao preto figurava a identidade com os animais, destituídos de alma. As ilusões humanistas não se destinavam aos pretos.

Diga-se de passagem, a maldade não cessou com a promulgação da Lei Áurea, em 1888, mas mostrou sua faceta mais perversa quando os pretos libertos foram expulsos das fazendas e abandonados à própria sorte, sem escolas, nem terras e empregos ${ }^{19}$. A mão de obra escrava foi substituída por mão de obra assalariada branca europeia.

Durante os primeiros vinte anos da Primeira República (1889-1930) todas as vertentes do nacionalismo (liberal, militarista, religioso, etc.), em maior ou menor grau, apresentavam um ponto em comum: os escravos libertos não configuravam a identidade desejada para o povo brasileiro. Deveriam desaparecer. Nas fazendas longe dos grandes centros foram libertados, ignorados e excluídos da vida social e quando se fala em nacionalismo, principalmente, aquele com conteúdo mais sentimental de exaltação patriótica e de valorização do trabalho, logo apareciam os problemas de cunho racial.

Para responder ao problema, a imigração, em grande medida, substituiu a força de trabalho escravo, mas tinha, também, a missão de branquear o país e fazer desaparecer a cor da pele indesejável. A política da eugenia adotada no país, na época, segundo Marques, tinha como objetivo aumentar a resistência biológica, a aptidão intelectual e a disposição para o trabalho pela prática de aperfeiçoamento da raça (de inspiração evolucionista) como forma de controle da população. Raça e cultura são os objetos de interesse dos estudos eugênicos, que encontraram campo fértil entre os intelectuais brasileiros do período republicano ${ }^{20}$.

A imagem do preto e do mestiço maculava a assepsia aristocrático-burguesa da maioria dos republicanos pouco esclarecidos e representava sérios obstáculos à ordem e ao progresso. A miséria e

\footnotetext{
${ }^{18}$ Uma autorreflexão machadiana mostra que os seres humanos são tratados como animais: "Um sujeito, ao pé de mim, dava a outro notícia recente dos negros novos, que estavam a vir, segundo cartas que recebera de Luanda; uma carta em que o sobrinho lhe dizia ter já negociado cerca de quarenta cabeças [...]”. (MACHADO DE ASSIS, 2010, p. 54).

${ }^{19}$ CARVALHO, op. cit., 2011

${ }^{20}$ MARQUES, Vera R. B. A medicalização da raça: médicos, educadores e discurso eugênico. Campinas/SP: UNICAMP, 1994.
} 
a pobreza foram vistas como vagabundagem e, esta, por sua vez, como fonte de criminalidade, vícios e doenças que precisavam ser combatidas por uma política de eugenia ${ }^{21}$.

A imigração foi uma saída, embora em Caio Prado Jr. observa-se outras facetas perversas do que aconteceu:

[...] a abolição não eliminou desde logo, pelo menos em alguns lugares, acentuados traços escravistas que permaneceram de fato e à margem do regime legal de trabalho livre. Mas [...] longe de constituírem obstáculos ao progresso e ao desenvolvimento do capitalismo, lhe têm sido altamente favoráveis, pois contribuem para a compressão da remuneração do trabalho, ampliando com isso a parte da mais-valia, e favorecendo por conseguinte a acumulação capitalista. O que sobra do escravismo representa assim um elemento de que o capitalismo se prevalece, e em que frequentemente se apoia, uma vez que o baixo custo de mão de obra torna possível em muitos casos à sobrevivência de empreendimentos de outra forma deficitários. ${ }^{22}$

Então, evidentemente, nos grandes centros, não cabe afirmar que os libertos representavam problemas, pelo contrário, mantinham o preço da mão de obra barata e estavam dispostos às mais brutais formas de exploração do trabalho. Ora, Brás Cubas, a célebre personagem machadiana, representa um desses burgueses liberais caridosos e bondosos que não enxergavam mais os pretos como escravos, mas como criados, no sentido de serviçais livres. A sua tolerância com os pretos mostra como deveria ser os novos modos de conduta das elites neocoloniais.

O potencial de reflexão e autorreflexão sobre a escravidão, proposto no livro Memórias póstumas de Brás Cubas, conduz o leitor a pensar que o mal é uma construção social e que se trata de um problema ético característico de um tempo histórico, a saber, o tempo que durou a escravidão. Como se ao final do período escravocrata, pretensamente, tenha-se colocado fim ao mal. Pelo contrário, o mal se reproduz para satisfazer as exigências instintivas reprimidas, como se mostra no tópico seguinte. Para melhor compreensão da problemática, há que se diferenciar a maldade da perversidade.

A perversidade é ilimitada e, mais uma vez, reclamou sua existência na ideia de que os pretos não mereciam viver no Brasil, senão como criados, diluídos num processo de miscigenação e gradual branqueamento da cor da pele e explorados no trabalho pelo novo regime (capitalista).

Observa-se que o saldo, daquele último capítulo de negativas, revela-se em desabafo de Brás Cubas: "Não tive filhos, não transmiti a nenhuma criatura o legado da nossa miséria." ${ }^{23}$ Acreditamos que revela mais do que as "rabugens de pessimismo" da personagem. Considerando a escravidão, revela o ceticismo machadiano em relação ao processo civilizatório. Afinal, que humanismo era aquele que conferia dignidade e direito apenas a uma parcela de humanidade - a parcela branca?

A faceta mais perversa ficou reservada ao desrespeito à Declaração dos Direitos do Homem e do Cidadão, promulgada em 1789, na França, cuja finalidade era preservar a dignidade humana e serviu de inspiração para os propagandistas republicanos no Brasil. Porém, durante o período escravocrata e também depois dele, fica a ressalva: os "direitos" tiveram a conotação de privilégios. Certamente, para os pretos as consequências disso foram duradouras, dado que se verifica, ainda hoje, a posição inferior que ocupam nos indicadores de qualidade de vida.

Historicamente, mesmo após a abolição da escravidão, o preconceito, a discriminação e a exclusão social ainda persistem de variadas formas no Brasil e em diferentes países, mostrando "que a humanidade tem potência para um mal infinito, do qual a lei e a razão não podem sequer prever, portanto prevenir, a

\footnotetext{
${ }^{21}$ Ibidem.

${ }^{22}$ PRADO JR., Caio. A revolução brasileira. $5^{\text {a }}$ ed. São Paulo: Brasiliense, 1977, p. 97.

${ }^{23}$ MACHADO DE ASSIS, op. cit., 2010, p. 317.
} 
proliferação originária. O mal é inicialmente, um fantasma"24.

A astúcia machadiana descreveu precisamente esse fantasma nas Memórias póstumas de Brás Cubas, um defunto autor, cujas reflexões e autorreflexões mostram sutilmente a perversidade da elite em relação aos escravos e como ela se reproduziu após o fim da escravidão.

\section{A reprodução do mal nas memórias póstumas}

Lendo e relendo o romance/ficção Memórias póstumas de Brás Cubas para analisar algumas de suas passagens de interesse para este artigo, inicialmente, não havia intenção de trazer o debate para uma metafísica que culpabiliza as forças malignas pelas maldades e perversidades cometidas pelo menino Brás Cubas. Em suas lembranças de defunto autor: "desde os cinco anos merecera eu a alcunha de "menino diabo'; e verdadeiramente, não era outra coisa; fui dos mais malignos do meu tempo, arguto, indiscreto, raquinas e voluntarioso." 25

Diante da autorreflexão machadiana, rejeitamos a existência de uma vontade diabólica como origem do mal. Naquele momento histórico, na sociedade escravocrata as maldades e as perversidades cometidas contra os pretos estavam suspensas de julgamento moral dado a sua permissividade e legalidade em consonância com os padrões do humanismo da época. A própria sociedade dava ao menino a liberdade de atentar contra os escravos.

Entretanto, nesse tópico retomamos as perversidades do menino, que ora são relembradas por Brás Cubas, com o objetivo de apontar as origens do mal, caracterizando-as como perversidades, mas procurando salientar que tudo que passa fica latente na vida mental daqueles que o sofreram, retornando em outro momento histórico para reproduzi-lo, caso da personagem Prudêncio.

Vejamos os exemplos no comportamento do menino Brás Cubas. Em ocasião solene em que estava reunida a sociedade seleta na casa dos Cubas, houve um jantar e logo em seguida foi colocada sobre a mesa doces e compotas, mas ninguém se servia porque o Dr. Vilaça, homem grave de quarenta e sete anos, casado e pai, estava recitando poemas. $\mathrm{O}$ menino, num arroubo de impaciência, começou a gritar e bater com os pés pedindo que lhe servissem os doces, mas foi retirado da sala por uma escrava. A culpa pela sua retirada da sala foi do Dr. Vilaça. Ele deveria ser punido. Nota-se a perversidade criativa na seguinte passagem: "Tanto bastou para que eu cogitasse uma vingança, qualquer que fosse, mas grande e exemplar, coisa que de alguma maneira o tornasse ridículo. [...] Não me contentava com o rabo de papel nem o rabicho da cabeleira; havia de ser coisa pior." ${ }^{26} \mathrm{O}$ homem foi seguido pelo menino até se deixar estar numa situação propícia para que a perversidade de súbito emergisse. Caminhando pela chácara com Dona Eusébia e trocando palavras de amor, o Dr. Vilaça beijou-a, mas o menino escondido atrás de uma moita viu tudo e saiu indiscretamente a gritar em meio aos convidados: “- O Dr. Vilaça deu um beijo em Dona Eusébia. [...] Foi um estouro esta minha palavra; a estupefação imobilizou a todos”27. O seu pai dizia: "Brejeiro, brejeiro", rindo.

Em outro exemplo do mesmo quilate, o defunto autor Brás Cubas relata que quebrou a cabeça da escrava porque lhe negara uma colher de doce de coco. Ainda não satisfeito jogou cinza no tacho, depois, disse ao pai que a escrava tinha jogado a cinza "por pirraça" para não lhe dar o doce. Quebrar a cabeça da escrava e jogar as cinzas no tacho são maldades, mas a mentira representa a perversidade, a engenhosidade reservada para o futuro como forma de punir a escrava, que certamente seria repreendida ou mesmo vergalhada. Vignoles assinala que as crianças apresentam traços de perversidade.

\footnotetext{
${ }^{24}$ VIGNOLES, op. cit., 1991, p. 58.

${ }^{25}$ MACHADO DE ASSIS, op. cit., 2010, p. 47.

${ }^{26}$ Ibidem, p. 55.

${ }^{27}$ Ibidem, p. 56.
} 
Ele cita o caso do jovem Rousseau, que se assemelha à atitude do menino Brás Cubas: “[...] por exemplo uma pequena mentira, como a de Rousseau adolescente, que, tendo roubado uma condecoração durante uma mudança, fez com que a empregada fosse acusada injustamente. A besteira de Jean-Jacques é maldosa, sua mentira é perversa" 28 . Conta a história que Rousseau pegou para si a condecoração (cujo valor real era apenas sentimental), mas sendo surpreendido com a peça disse que foi a empregada quem havia lhe dado. Uma vez diante da empregada, não hesitou, dissimulou e sustentou sua versão.

A perversidade é inconfessável e se esconde atrás de uma maldade justificada, tal como fazia Brás Cubas e o fez o jovem Rousseau. A moral que está por trás da perversidade assegura uma justificativa racional e tida como digna de defesa pelo perverso. Guardadas as diferenças e os potenciais de destruição e perversidade contra o outro, a defesa do nazista Eichmann, no tribunal em Jerusalém, representa bem a perversidade justificada. O problema é que a razão da perversidade se sustenta por ser social ou antissocial. Social quando aceita por uma sociedade sem que haja questionamentos, caso da elite escravocrata brasileira; antissocial quando voltada para a destruição explícita da cultura. Em ambos os casos avançam para a destruição final.

No capítulo XI, “O menino é pai”, Brás Cubas relembra sua infância:

Prudêncio, um moleque de casa, era o meu cavalo de todos os dias; punha as mãos no chão, recebia um cordel nos queixos, à guisa de freio, eu trepava-lhe ao dorso, com uma varinha na mão, fustigava-o, dava mil voltas a um e outro lado, e ele obedecia, - algumas vezes gemendo, - mas obedecia sem dizer palavra, ou, quando muito, um - 'ai, nhonhô!'- ao que eu retorquia: - 'Cala a boca, besta!'29

No capítulo LXVIII, “O vergalho”, já homem, Brás Cubas relata que num de seus passeios viu o preto Prudêncio, agora liberto, chicotear outro preto (seu escravo), em praça pública.

[...] era um preto que vergalhava outro na praça. O outro não se atrevia a fugir; gemia somente estas únicas palavras: - 'Não, perdão, meu senhor; meu senhor, perdão!' Mas o primeiro não fazia caso, e, a cada súplica, respondia com uma vergalhada nova. [...] Parei, olhei... Justos céus! Quem havia de ser o do vergalho? Nada menos que o moleque Prudêncio, - o que meu pai libertara alguns anos antes. ${ }^{30}$

O mal reproduz o mal? Particularmente, a sagacidade machadiana aflora na autorreflexão sobre a maldade e a perversidade, cabendo a si próprio a maior parte do sofrimento. "O mal cometido por um encontra sua réplica no mal sofrido por outro; é neste ponto de intersecção maior que o grito da lamentação é mais agudo, quando o homem se sente vítima da maldade do homem"31.

O filósofo Paul Ricoeur aponta para o protesto dos que sofrem e faz lembrar o sentimento amargo e áspero descrito no prólogo do livro Memórias póstumas de Brás Cubas. Machado de Assis produz imagens com sua arte fictícia cheirando a realidade para mostrar a condição humana. Nem por isso, deixa de considerar a sua própria condição de homem preto, literato reconhecido e respeitado, vivendo em meio aos horrores da escravidão, mas percebendo que assim é, assim fora e assim seria naquela sociedade.

A personagem Brás Cubas refletiu sobre sua conduta nas memórias póstumas, mas ele representa $\mathrm{o}$ espírito burguês daquela sociedade liberal com mentalidade escravocrata. Prudêncio, por sua vez, sofreu o mal e o reproduziu.

Era um modo que o Prudêncio tinha de se desfazer das pancadas recebidas, -

\footnotetext{
${ }^{28}$ VIGNOLES, op. cit., 1991, p. 55.

${ }^{29}$ MACHADO DE ASSIS, op. cit., 2010, p. 47.

${ }^{30}$ Ibidem, p. 171.

${ }^{31}$ RICOEUR, Paul. O Mal: um desafio à Filosofia e à Teologia. Trad. Maria da Piedade E. Almeida. Campinas/SP: Papirus, 1988, p. 25.
} 
transmitindo-as a outro. Eu, em criança, montava-o, punha-lhe um freio na boca, e desancava-o sem compaixão; ele gemia e sofria. Agora, porém, que era livre, dispunha de si mesmo, dos braços, das pernas, podia trabalhar, folgar, dormir, desagrilhoado da antiga condição, agora é que ele se desbancava: comprou um escravo, e ia-lhe pagando, com alto juro, as quantias que de mim recebera. Vejam as sutilezas do maroto!32

Ao reconhecer as sutilezas do maroto, parece haver a configuração da arte da vingança, quando, na verdade, estamos diante do mal se reproduzindo numa dialética que responde, ao mesmo tempo, aos instintos agressivos (naturalismo) e aos padrões societários vigentes (humanismo). A perversidade disposta na condição humana aflora.

Brás Cubas refletiu sobre o que fez no passado com o escravo e Prudêncio, uma vez liberto, pagou com alto juro o que sofreu, enquanto outra vítima - outro preto - lamentou o sofrimento, ressentindo-se, talvez guardando o mal para descontar num outro no futuro. Para Freud, tudo o que passou fica preservado na vida mental.

Esse pressuposto freudiano fundamenta a reprodução do mal. As sutilezas de Machado de Assis fazem Brás Cubas pensar o seguinte: "Logo que meti mais dentro a faca do raciocínio achei-lhe um miolo gaiato, fino, e até profundo. Prudêncio tinha de desfazer as pancadas recebidas transmitindo-as a outro. Eu, em criança, montava-o, punha-lhe um freio na boca, e desancava-o sem compaixão; ele gemia e sofria" ${ }^{33}$.

O problema do mal se revela na perversidade, cuja imprevisibilidade (devido à latência) converte-se em possibilidade histórica. O Prudêncio estava livre, poderia dispor de seus braços e pernas para trabalhar e deixar a condição de oprimido, mas "desagrilhoado da antiga condição, agora é que ele se desbancava: comprou um escravo, e ia-lhe pagando, com alto juro, as quantias que de mim recebera" ${ }^{4}$.

Prudêncio encarnou a consciência histórica do opressor e perversamente movimentou a roda da reprodução. Ele introjetou/internalizou a cultura dominante e se tornou um veículo dela. Uma vez introjetada/internalizada a cultura dominante, significa que houve um processo de identificação do oprimido com o opressor, já que os oprimidos "podem estar emocionalmente ligados a seus senhores: apesar de sua hostilidade com eles, podem ver neles os seus ideais" 35 . A esse fenômeno Freud chama de narcisismo. Um fenômeno da cultura, cuja pretensa superioridade reivindica para si o direito de desprezar outras culturas. Tal fenômeno pode afetar, também, os indivíduos de uma mesma unidade cultural.

Prudêncio, por exemplo, quando se tornou homem livre passou a fazer parte da cultura, ganhando o direito de desprezar os pretos escravos, compensando as injustiças que sofreu quando era escravo, reproduzindo tudo no outro. A ideia é a seguinte, antes ser um preto livre, mesmo que atormentado por ser preto numa cultura branca, e exercer a sua cota de opressão, do que ser um escravo e receber vergalhadas ${ }^{36}$.

Notadamente, a liberdade de Prudêncio foi condenada a dominação sociocultural, cujo horizonte permite vislumbrar a sua servidão ajustada de serviçal livre, indigno de direitos plenos devido à cor de sua pele e origem. O horizonte de Prudêncio foi o mesmo de milhões de brasileiros, que, enquanto serviçais livres, introjetaram/internalizaram a cultura dominante, "a saber, as formas escravistas de exploração do trabalho, e os ínfimos padrões materiais e culturais que daí decorrem para a grande massa da população

\footnotetext{
${ }^{32}$ MACHADO DE ASSIS, op. cit., 2010, 172.

${ }^{33}$ Ibidem, p. 172.

${ }^{34}$ Ibidem, p. 172.

${ }^{35}$ FREUD, op. cit., 1996, p. 23.

${ }^{36}$ Freud (1996, p. 23) diz o seguinte: "Não há dúvida de que alguém pode ter sido um plebeu infeliz, atormentado por dívidas e pelo serviço militar, mas, em compensação, não deixava de ser um cidadão romano, com sua própria quota na tarefa de governar outras nações e ditar leis."
} 
[...], que por vias diretas ou indiretas vão afetar o conjunto da vida econômica e social brasileira" ${ }^{37}$. Cabe ressaltar que esse foi o processo de integração viabilizado a título de projeto de nação, de processo civilizatório, aos pretos, mestiços, índios e pobres.

No bojo dessa reflexão sobre a reprodução do mal como uma construção social, observa-se que a perversidade torna possível pensar e vislumbrar todos os horrores já cometidos ao longo da história, bem como o seu devir, latente. Portanto, extirpar o mal não é possível, é mais uma ilusão do humanismo, mas vislumbrar a sua possibilidade em qualquer tempo e a qualquer momento é um exercício somente para quem o vivenciará. $\mathrm{O}$ triunfo da perversidade não se esgota em si, mas na latência e concretude de seu exercício.

A metafísica ${ }^{38}$ humanista aponta os valores de dignidade humana e os direitos fundamentais para o processo civilizatório, porém a ilusão humanista ainda é restrita. Nesse sentido, a invenção dos Direitos Humanos $^{39}$ se tornou a principal e a mais formidável das invenções, enquanto mecanismo de proteção da humanidade. Toca o sentimento e a consciência das pessoas no que concerne a questões importantes em relação ao preconceito, o racismo, a xenofobia, associada à ideia de universalidade dos direitos. Evidenciase o direito à proteção da pessoa humana por ser um ente dotado de valor moral.

O Brasil é um signatário dos sistemas internacionais e interamericano dos direitos e, hoje, tem leis que favorecem o respeito aos Direitos Humanos, no sentido em que se deseja, de introjetar/internalizar os valores necessários à consolidação do processo civilizatório. Contudo, a dominação, o preconceito, a opressão, a exclusão, a violência, a injustiça social, a exploração, a expropriação do trabalho, etc., ainda perpetuam-se na existência de cada indivíduo preto, mestiço, índio, pobre, etc., que sofre e reproduz o mal.

Para análise do fenômeno, há que se considerar, portanto, a dialética entre humanismo e naturalismo, isto é, precisamos pensar o homem ao mesmo tempo como um fato natural - como uma espécie em evolução, como todas as outras -, e como portador de valores absolutos, dotados de direitos como valor moral. Observa-se a pontualidade da seguinte premissa freudiana: o instinto de destruição nasce em cada novo ser humano. Evidentemente, diferentes formas de violência, injustiça, opressão, dominação sociocultural, etc., podem se perpetuar nesse processo.

Recebido em: 18/04/2016. Aprovado em: 31/05/2016.

\footnotetext{
${ }^{37}$ PRADO JR., op. cit., 1977, p. 137.

38 “[...], a metafísica é um sistema de ilusões que, por não serem mais que ilusões, reafirmam o naturalismo, mas que, enquanto conjunto de ilusões constitutivas da vida humana, acabam por especificar de uma maneira irredutível uma tal vida." (BIMBENET, 2014, p. 24).

${ }^{39}$ A Declaração Universal dos Direitos Humanos foi promulgada em 1948 como medida para evitar barbáries como, por exemplo, as cometidas no holocausto, durante a Segunda Guerra Mundial.
} 